\title{
Protective role of salt in catalysis and maintaining structure of halophilic proteins against denaturation
}

\author{
Rajeshwari Sinha and Sunil K. Khare* \\ Department of Chemistry, Indian Institute of Technology Delhi, Delhi, India
}

\section{Edited by:}

Aharon Oren, The Hebrew

University of Jerusalem, Israel

\section{Reviewed by:}

Aharon Oren, The Hebrew

University of Jerusalem, Israel

Dominique Madern, Institut de

Biologie Structurale, France

*Correspondence:

Sunil K. Khare, Enzyme and

Microbial Biochemistry Laboratory,

Department of Chemistry, Indian

Institute of Technology, Delhi, MS

801 (A), Hauz Khas, New Delhi

110016, India

e-mail: skhare@rocketmail.com;

skkhare@chemistry.iitd.ac.in
Search for new industrial enzymes having novel properties continues to be a desirable pursuit in enzyme research. The halophilic organisms inhabiting under saline/ hypersaline conditions are considered as promising source of useful enzymes. Their enzymes are structurally adapted to perform efficient catalysis under saline environment wherein nOn-halophilic enzymes often lose their structure and activity. Haloenzymes have been documented to be polyextremophilic and withstand high temperature, $\mathrm{pH}$, organic solvents, and chaotropic agents. However, this stability is modulated by salt. Although vast amount of information have been generated on salt mediated protection and structure function relationship in halophilic proteins, their clear understanding and correct perspective still remain incoherent. Furthermore, understanding their protein architecture may give better clue for engineering stable enzymes which can withstand harsh industrial conditions. The article encompasses the current level of understanding about haloadaptations and analyzes structural basis of their enzyme stability against classical denaturants.

Keywords: halophiles, haloadaptations, structure, denaturants, secondary structure, tertiary structure

\section{INTRODUCTION}

Halophiles are the class of extremophiles which inhabit saline/hypersaline habitats. Halophilic proteins retain their structural and functional integrity under such high salt conditions (Oren, 2008). Certain unique structural features enable them to sustain their structure and physiological activities at high salt. These proteins, thus offer a unique model system to decipher structure function modulation under saline environment.

A perfect model that accurately explains how salts stabilize a protein is still debatable. Earlier studies on some of the extreme halophilic and haloarchaeal enzymes like Haloarcula marismortui malate dehydrogenases (Hm MDH) (Mevarech et al., 1977) and Halobacterium salinarum ferredoxins (Gafni and Werber, 1979) indicated that their enzymatic properties are fully expressed only in the presence of salt and that the gradual withdrawal of salt leads to the unfolding of protein. However, current understanding has emerged that requirements of high salt for activity and stability would rather be a restrictive definition of the halophilic proteins isolated from extreme halophiles. In many cases such as $\mathrm{MDH}$ from Salinibacter ruber (Madern and Zaccai, 2004), $\alpha$-amylase from Har. hispanica (Hutcheon et al., 2005), the enzyme is not completely inactivated in the absence of salt. $\mathrm{Hm} \mathrm{MDH}$ from different studies have shown the enzyme to be stable at millimolar concentration of salts in the presence of divalent cations or coenzyme (Bonneté et al., 1994; Madern and Zaccai, 1997).

Haloadaptations of proteins viz. presence of increased number of acidic amino acid residues on protein surface, smaller hydrophobic patches as well as salt bridges between acidic and strategically positioned basic residues have been previously defined (Lanyi, 1974; Eisenberg et al., 1992; Danson and Hough, 1997; Madern et al., 2000). Since then, structural analyses have revealed two significant differences in the characteristics of the surface of the halophilic enzymes. The first of these is that the excess of acidic residues are predominantly located on the enzyme surface forming a hydration shell that protects the enzyme from aggregation under high salinity. Secondly, the surface also displays a significant reduction in exposed hydrophobic character, which arises from a reduction in surface-exposed lysine residues. Oren (2013) recently reviewed the occurrence of acidic proteomes in halophiles for a better understanding of the modes of haloadaptation at the cellular level.

The halophilic proteins remain highly soluble in high salt milieu whereas their non-halophilic counterparts precipitate. The most appropriate model that explains the changes in solvent properties of halophilic proteins is the "solvation-stabilization model" (Ebel et al., 1999; Costenaro et al., 2002; Ebel et al., 2002). The thermodynamic basis in such cases has been well explained by Zaccai (2013). The model reflects that solubility, and changes in stability are intrinsically coupled. Extensive characterization of orthologous enzymes from extreme halophilic microorganisms, have shown that the unique adaptive feature which is shared by stable and unstable halophilic proteins is their high solubility at high salt concentration (Coquelle et al., 2010). Crystallographic analysis on halophilic and non-halophilic MDH from Salinibacter ruber and Chloroflexus aurantiacus respectively successfully established that acidic amino acids in the former were involved in disruption of pentagonally arranged network of water molecules within the hydration shell of halophilic protein (Talon et al., 2014). The acidic enrichment was attributed to an "evolutionary innovation" which enabled the protein to adapt under saline stress and suitably alter inherent protein-solvent interactions. A correlation between an increase of acidic amino acid and a 
favorable change of solubility in halophilic proteins has also been established by Tadeo et al. (2009).

A good amount of data has emerged in recent years which indicate a protective role of salt in stabilizing these proteins against classical denaturants. The present article encompasses the major haloadaptations directed toward understanding the basis of stability against classical denaturants. A critical understanding of how halophilic proteins, under the influence of salt, retain structural and functional integrity amidst denaturing milieu will provide guidelines and templates for engineering stable proteins/enzymes for industrial applications.

\section{BASIC ASPECTS IN PROTEIN STABILITY}

The effects of salt on structure and function of non-halophilic proteins have been well worked out. The presence of high salt in a protein solution will have the following implications: disturbance in local water structure around the protein; decreased propensity for intermolecular hydrogen bonds, affecting protein solubility, binding, stability and crystallization; increased surface tension of water, striping off the essential water layer from the protein surface and increased hydrophobic interactions, causing protein aggregation and precipitation. To sum up, the protein structure and consequent functions are adversely affected by high salt concentrations.

\section{PROTEIN DENATURATION}

Denaturation of a protein refers to the loss of biological activity due to structural changes in the protein brought about by physical or chemical factors such as $\mathrm{pH}$, temperature, salt, detergents, organic solvents or chaotropic agents. The secondary, tertiary or quaternary structures are largely affected upon denaturation. Some of the important mechanisms of protein denaturation are (http://class.fst.ohio-state.edu/FST822/lectures/Denat.htm):

- High temperature weakens the inherent bonds in protein. Further heating disrupts the hydrogen bonds within protein and new hydrogen bonds are established with surrounding water molecules thus breaking the helical structure.

- Water miscible solvent (less polar than water) lowers the dielectric constant of the system thereby strengthening electrostatic interactions among molecules. The protein largely unfolds exposing hydrophobic groups to the solvent causing aggregation and precipitation.

- Proteins are usually more soluble in dilute salt solutions because the salts in their ionic forms associate with opposite charges within the protein moiety, leading to increased hydration of the surface. However, at very high salt concentration, the increased surface tension of water generates a competition between protein and salt ions for hydration. Salts strip off the essential layer of water molecules from the protein surface eventually denaturing the protein.

- Protein denaturation by urea may occur by direct or indirect mechanisms (Lindgren and Westlund, 2010). Urea may directly interact with proteins by hydrogen bonding with the polarized areas on protein surface, weakening intermolecular bonds and protein structure. Guanidium hydrochloride $(\mathrm{GdmCl})$ has a similar mechanism but is a more effective denaturant than urea. In an indirect mechanism, urea may disturb the water structure causing destabilization of the protein.

- Acids and bases alter the $\mathrm{pH}$ of the solution as well as disrupt the salt bridges which are primarily stabilizing ionic interactions between opposite charged amino acid residues on protein surface. Heavy metal salts viz. $\mathrm{Hg}^{2+}, \mathrm{Cd}^{2+}, \mathrm{Pb}^{2+}, \mathrm{Ag}^{+}$similarly disrupt salt bridges or disulfide linkages in proteins leading to an insoluble metal protein complex. SDS induced protein denaturation involved unfolding of tertiary structure and "chain expansion" (Bhuyan, 2010).

\section{SALT IS ESSENTIAL FOR MAINTAINING STRUCTURE AND FUNCTION OF HALOPHILIC PROTEINS}

Evidently, presence of salt is a prerequisite for functioning of halophilic proteins (Mevarech et al., 2000). Large number of studies have been undertaken to investigate the role of salt in regulating structures and function of extremely/ moderately halophilic enzymes. Some of these are summarized in Table 1. The data suggests at the precise salt dependence of protein structures in halophiles. Majority of the studies indicate loss of enzymatic activity upon salt removal. These observations have been well supported by structural data. While the protein remained predominantly unfolded or randomly coiled in salt free medium, salt promoted increase in negative ellipticity and subsequent refolding. The effect of other metal ions on the activity and stability of halophilic enzymes have also been investigated. Differential roles of divalent $\mathrm{Ca}^{2+}$ and monovalent $\mathrm{Na}^{+}$in preventing unfolding and regulation of catalytic activity respectively was also reported recently for Bacillus sp. EMB9 protease (Sinha and Khare, 2013a). Salt and divalent metal ions were reported to independently stabilize and regulate catalysis and folding of RNase H1 from Hbt. sp. NRC-1 (Tannous et al., 2012). In a different study, changes in tertiary structure of ferredoxin were associated with removal of $\mathrm{Fe}^{3+}$ (Gafni and Werber, 1979).

However, anomalies to the above generic trend cannot be ruled out. S. ruber $\mathrm{MDH}$ and Har. hispanica amylase remained completely active and structured even in absence of salt (Madern and Zaccai, 2004; Hutcheon et al., 2005). Likewise, glutamate dehydrogenase $(\mathrm{GDH})$ from Hbt. salinarum was catalytically active under both low and high salt (Ishibashi et al., 2002). The exact reason for such stability is not known but it is plausible that the folded protein is structurally rigid enough to remain folded in the correct conformation and withstand non-saline environment.

\section{EFFECT OF DENATURANTS ON HALOPHILIC PROTEINS: PROTECTIVE ROLE OF SALTS}

Haloadaptations are perceived to impart stability to halophilic proteins against denaturants. Increasing evidences have gathered now to indicate the role of salt in protecting proteins against denaturants. Studies show that in the presence of salt, secondary and tertiary structure are maintained rigidly against denaturants. However, the question remains the precise mechanism which enables this stability in halophilic enzymes. Few of the important instances have been discussed below. 
Table 1 | Effect of salt on activity and structure of halophilic enzymes.

\begin{tabular}{|c|c|c|c|c|}
\hline Enzyme & Microorganism & $\begin{array}{l}\text { Salt range } \\
\text { investigated }\end{array}$ & Structure-function correlation & Reference \\
\hline Malate dehydrogenase & $\begin{array}{l}\text { extreme halophilic } \\
\text { bacteria from the Dead } \\
\text { Sea }\end{array}$ & $0-4.0 \mathrm{M} \mathrm{NaCl}$ & $\begin{array}{l}\text { Salt withdrawal caused loss of enzymatic } \\
\text { activity } \\
\text { Distorted ellipticity with complete loss of } \\
\text { secondary structure }\end{array}$ & $\begin{array}{l}\text { Pundak and Eisenberg, } \\
1981\end{array}$ \\
\hline $\begin{array}{l}\text { NADP-glutamate } \\
\text { dehydrogenase }\end{array}$ & Haloferax mediterranei & $33 \mathrm{mM}$ & $\begin{array}{l}\text { Fluorescence spectra remained unaltered until } \\
\mathrm{KCl} \text { concentration was lowered to } 33 \mathrm{mM} \\
\text { At } 33 \mathrm{mM} \mathrm{KCl} \text {, time dependent decay of } \\
\text { activity and complete fluorescence quenching }\end{array}$ & Ferrer et al., 1998 \\
\hline Thermolysin & $\begin{array}{l}\text { Bacillus } \\
\text { thermoproteolyticus }\end{array}$ & $1-5 \mathrm{M} \mathrm{NaCl}$ & $\begin{array}{l}\text { Activity enhanced by } 15 \text { fold in presence of } \\
4 \mathrm{M} \mathrm{NaCl} \\
\text { Heat stability doubled in presence of } 1.5 \mathrm{M} \\
\mathrm{NaCl} \text { supported by CD spectral data }\end{array}$ & Inouye et al., 1998 \\
\hline $\begin{array}{l}\text { Transducers HtrX and } \\
\operatorname{HtrX1}\end{array}$ & Halobacterium salinarum & $\begin{array}{l}0.2-3.6 \mathrm{M} \mathrm{NaCl} \text { or } \\
\mathrm{KCl}\end{array}$ & $\begin{array}{l}\text { Under low-ionic-strength conditions ( } \sim 0.2 \mathrm{M} \\
\mathrm{NaCl} \text { or } \mathrm{KCl}) \mathrm{HtrXI} \text { assumed a random coil } \\
\text { structure while } \mathrm{HtrX} \text { retained } 85 \% \alpha \text {-helicity } \\
\text { Addition of } \mathrm{NaCl} \text { or } \mathrm{KCl} \text { led to increase in } \\
\alpha \text {-helical characters for both }\end{array}$ & Larsen et al., 1999 \\
\hline Fe2-S2 ferredoxin & Halobacterium salinarum & $0.1-4.5 \mathrm{M}$ & $\begin{array}{l}\text { Unfolding at low salt; time dependent loss of } \\
\text { secondary structure } \\
\text { Destabilization of the Fe2-S2 center of } \\
\text { ferredoxin at low salt }\end{array}$ & $\begin{array}{l}\text { Bandyopadhyay and } \\
\text { Sonawat, } 2000\end{array}$ \\
\hline $\begin{array}{l}\text { Dihydrofolate reductase } \\
\text { (DHFR) }\end{array}$ & Haloferax volcanii & $0.12 \mathrm{M}$ and $3 \mathrm{M} \mathrm{KCl}$ & $\begin{array}{l}\mathrm{Hv} \text { DHFR inactivation below } 0.5 \mathrm{M} \mathrm{KCl} \\
\text { Secondary and tertiary structures showed } \\
\text { analogy with the activity trend }\end{array}$ & Wright et al., 2002 \\
\hline $\begin{array}{l}\text { Nucleoside diphosphate } \\
\text { kinase (NDK) }\end{array}$ & Natrialba magadii & $90 \mathrm{mM}-3.5 \mathrm{M} \mathrm{NaCl}$ & $\begin{array}{l}\text { Red shift of } \lambda_{\max } \text { from } 333 \mathrm{~nm} \text { (at } 1.75 \mathrm{M} \mathrm{NaCl} \text { ) } \\
\text { to } 340 \mathrm{~nm} \text { (without } \mathrm{NaCl} \text { ) in fluorescence } \\
\text { spectra }\end{array}$ & Polosina et al., 2002 \\
\hline $\begin{array}{l}\text { Isocitrate dehydrogenase } \\
\text { (ICDH) }\end{array}$ & Haloferax volcanii & $0-5.0 \mathrm{M} \mathrm{NaCl}$ & $\begin{array}{l}\text { Dissociation of the protein at low } \mathrm{NaCl} \\
\text { High } \alpha \text {-helical content at } 4 \mathrm{M} \mathrm{NaCl} \text { was } \\
\text { indicative of a fully folded active enzyme while } \\
\text { partially folding observed at low concentration } \\
\text { Irreversible denaturation below a threshold } \\
\text { concentration }\end{array}$ & Madern et al., 2004 \\
\hline$\alpha$-amylase $\mathrm{AmyH}$ & $\begin{array}{l}\text { halophilic archaeon } \\
\text { Haloarcula hispanica }\end{array}$ & $0-4.0 \mathrm{M} \mathrm{NaCl}$ & $\begin{array}{l}\text { Retained structural and functional integrity in } \\
\text { the absence of salt } \\
\text { Intrinsic fluorescence suggest that it did not } \\
\text { unfold at low salt but may get slightly more } \\
\text { loosely folded } \\
\text { Very stable in high-salt buffer }\end{array}$ & Hutcheon et al., 2005 \\
\hline Esterolytic enzyme LipC & $\begin{array}{l}\text { archaeon Haloarcula } \\
\text { marismortui and } \\
\text { overexpressed in E. coli } \\
\text { BL21 }\end{array}$ & $0-5.1 \mathrm{M} \mathrm{NaCl}$ & $\begin{array}{l}\text { Far UV-CD showed maximum negative } \\
\text { ellipticity at } 3.4 \mathrm{M} \mathrm{NaCl} \text {. } \\
\text { Considerable loss of secondary structure, as } \\
\text { salt concentration was varied away from the } \\
\text { optimal value }\end{array}$ & Rao et al., 2009 \\
\hline Recombinant esterase & $\begin{array}{l}\text { Haloarcula marismortui, } \\
\text { (Hm EST), cloned and } \\
\text { overexpressed in E. coli }\end{array}$ & $0-500 \mathrm{mM} \mathrm{KCl}$ & $\begin{array}{l}\text { Unfolded protein in salt-free medium } \\
\text { Pronounced negative ellipticity, increase in } \\
\alpha \text {-helical content upon addition of } \mathrm{KCl}\end{array}$ & Müller-Santos et al., 2009 \\
\hline
\end{tabular}


Table 1 | Continued

\begin{tabular}{|c|c|c|c|c|}
\hline Enzyme & Microorganism & $\begin{array}{l}\text { Salt range } \\
\text { investigated }\end{array}$ & Structure-function correlation & Reference \\
\hline Protease & Geomicrobium sp. EMB2 & $0-10 \%(w / v) \mathrm{NaCl}$ & $\begin{array}{l}\text { Secondary structure of the protease unfolded } \\
\text { in salt-free medium } \\
\text { Structure regained by inclusion of } 2-5 \% \mathrm{NaCl}\end{array}$ & Karan and Khare, 2011 \\
\hline $\begin{array}{l}\text { Nep extracellular } \\
\text { protease }\end{array}$ & Natrialba magadii & $1.0-3.0 \mathrm{M} \mathrm{NaCl}$ & $\begin{array}{l}\text { Irreversible denaturation, aggregation and loss } \\
\text { of activity of Nep in the absence of salt; } \\
\text { random coil structure in CD spectra } \\
\text { Secondary conformation sufficiently folded in } \\
\text { salinity profile }\end{array}$ & Souza et al., 2012 \\
\hline
\end{tabular}

\section{EFFECT OF TEMPERATURE}

Thermal stability in proteins is attributed to the combination of factors like improved core packing, increased ionic interactions, decreased hydrophobic surface area, helix stabilization and reduced conformational strain (Sinha and Khare, 2013b). Stability at high temperatures in halophilic proteins has been found to be regulated by presence of salt. $\beta$-lactamase from halophilic Chromohalobacter sp. retained $\sim 82 \%$ of its activity after heat treatment at $100^{\circ} \mathrm{C}$ for $5 \mathrm{~min}$ (Tokunaga et al., 2004). This was indicative of a "reversible renaturation" of the lactamase induced by salt. Hbt. salinarum NDK also refolded back post heat treatment in a similar manner at higher concentrations of salt (Ishibashi et al., 2002). "Irreversible aggregation" may have possibly been averted due to the presence of acidic amino acid residues on the protein surface. In another study, higher thermal stability was imparted to Hbt. sp. SP1(1) by $4 \mathrm{M} \mathrm{NaCl}$ than $2 \mathrm{M}$ (Akolkar and Desai, 2010).

\section{EFFECT OF CHAOTROPIC AGENTS}

Investigations on the effect of urea or $\mathrm{GdmCl}$ on some halophilic proteins revealed that these are relatively more stable toward denaturation compared to their non-halophilic analog (Dodia et al., 2008; Karan and Khare, 2011). Protective role of salt against urea induced denaturation has been evidenced in case of NDK from Nab. magadii (Polosina et al., 2002). At $3.5 \mathrm{M} \mathrm{NaCl}$, it retained complete activity even at $6 \mathrm{M}$ urea. This unique stability was attributed to the possible formation of strong intersubunit contacts within the quaternary structure of the halophilic protein which may have imparted stability to the subdomains and prevented denaturation. Fluorescence spectral analysis established that Har. hispanica $\alpha$-amylase, at $4 \mathrm{M} \mathrm{NaCl}$ remained fully folded and conformationally active even in the presence of $6 \mathrm{M}$ urea (Hutcheon et al., 2005). The protein was less structured in absence of salt and gradually lost its overall structure upon increasing urea concentrations. It is likely that charge screening effect imposed by salt ions may have prevented the urea from coming in close vicinity of the polar patches on halophilic protein thereby averting their interaction and subsequent denaturation.

\section{EFFECT OF ORGANIC SOLVENTS}

Organic solvents behave as mild chaotropic agents. They disrupt hydrogen bonds between protein subunits and reduce the catalytic efficiency by affecting the critical water concentration at the active site. Solvent stability is increasingly being evidenced as a generic trait among halophilic enzymes (Gupta and Khare, 2009). The presence of high salt reduces the water activity significantly. Halophilic enzymes are thus uniquely adapted to function in low water/ non-aqueous media (Kumar and Khare, 2012). Significant solvent stability among halophilic enzymes has been reported by different groups (Shafiei et al., 2011; Li and Yu, 2012; Li et al., 2012; Sinha and Khare, 2013a). However, very little has been investigated about the structure of halophilic enzymes in organic solvents.

Recently, the solvent induced conformational changes have been assessed. Fluorescence investigations of halophilic alcohol dehydrogenase $(\mathrm{ADH} 2)$ from $H f x$. volcanii affirmed that salt influences the correct folding of proteins in organic solvents (Alsafadi and Paradisi, 2013). The $\alpha$-helical content of Geomicrobium sp. protease remained unaffected in $50 \%(\mathrm{v} / \mathrm{v})$ $\mathrm{n}$-hexane and $\mathrm{n}$-decane in presence of $5 \%(\mathrm{w} / \mathrm{v}) \mathrm{NaCl}$ (Karan and Khare, 2011). Withdrawal of salt caused loss of $\alpha$-helical structure.

\section{EFFECT OF MUTATIONS}

Preliminary understanding about the mechanism of salt supported structural protection has also emerged from site directed mutagenesis (SDM) experiments. The importance of acidic peptide motif in halophilic enzymes to withstand saline stress was shown by Evilla and Hou (2006). Presence of insertion peptide in extreme halophile $H b t$. sp. NRC-1 cysteinyl tRNA synthetase (CysRS) showed strong salt dependence, and enhanced enzyme stability at low salt. Deletion of the motif reduced aminoacylation efficiency.

Extensive SDM on halophilic MDH from Har. marismortui produced a mutant which was more "halophilic" than the wild type enzyme (Madern et al., 1995). Its structure was solved allowing highlighting the important role of protein solvent interactions in the stabilization of a halophilic protein (Richard et al., 2000). Others SDM studies on Hm MalDH have also demonstrated the important role of anion binding site in the stabilization process (Madern et al., 2000; Irimia et al., 2003; Madern and Ebel, 2007). Mutation of several solvent exposed acidic amino acid residues with lysine in Hfx. mediterranei glucose dehydrogenase resulted in proteins displaying a slightly less halophilic behavior than the wild type enzyme (Esclapez et al., 2007). Mutation studies on glucose dehydrogenase and isocitrate dehydrogenase from extremely halophilic Archaea $H f x$. mediterranei and $H f x$. volcanii have also 
recently contributed to understanding of the molecular basis of salt tolerance for halophilic adaptation (Esclapez et al., 2013).

Replacement of 7 Ser residues in thermolysin by Asp improved stability and activity of its mutants (Takita et al., 2008). In the presence of $4 \mathrm{M} \mathrm{NaCl}$, hydrolytic activity of all mutants increased 17-19 folds. Halophilic characteristics were imparted to Pseudomonas NDK by replacing 2 Ala residues at its C-terminal end with acidic residues (Glu-Glu) (Tokunaga et al., 2008). Conversely, introduction of Ala-Ala into Halomonas sp. 593 NDK (Ha NDK) in place of Glu-Glu caused loss of enzyme halophilicity and critically affected the enzyme properties as well as secondary structure. While the wild type Ha NDK remained stable against dilution induced inactivation, the mutant form was easily irreversibly destabilized by dilution, regardless of presence of salt.

Above studies highlight that protein halophilicity bears a strong correlation with (i) the necessity and importance of acidic amino acid residues on its surface and (ii) the presence of salt which serves important role in restoring/preserving functionality in a halophilic enzyme. On the basis of available data, we may infer that there possibly exists a subset among halophilic proteins which successfully retain structure and activity even under unfavorable conditions. Although, this cannot be generalized, the ability of moderately halophilic enzymes to withstand denaturing environments has not been explored much and provides ample scope for future research.

\section{CONCLUSION}

The article reviews the present understanding about the responses of halophilic enzymes in solution toward chaotropic reagents and denaturants. Salt is essential in maintaining native structure of halophilic proteins. Sufficient experimental evidences conclude that salt significantly contributes in the modulation of the protein structure/activity toward different chaotropic conditions. The salt induced protective effect on the structure against chaotropic agents, temperature and solvents as well the corresponding structural transitions establish a unique structure-function correlation in halophilic enzymes. Comprehending their differential behavior and stability under harsher conditions could lead to better understanding about the biochemical and biophysical characteristics of these proteins and their exploitation for applications in biocatalysis or biotransformation under saline or low water conditions.

\section{ACKNOWLEDGMENTS}

The financial support to the study by the Department of Biotechnology and research fellowship to Rajeshwari Sinha by the Council of Scientific and Industrial Research (Govt. of India) is gratefully acknowledged.

\section{REFERENCES}

Akolkar, A. V., and Desai, A. J. (2010). Catalytic and thermodynamic characterization of protease from Halobacterium sp. SP1(1). Res. Microbiol. 161, 355-362. doi: 10.1016/j.resmic.2010.04.005

Alsafadi, D., and Paradisi, F. (2013). Effect of organic solvents on the activity and stability of halophilic alcohol dehydrogenase (ADH2) from Haloferax volcanii. Extremophiles 17, 115-122. doi: 10.1007/s00792-012-0498-0

Bandyopadhyay, A. K., and Sonawat, H. M. (2000). Salt dependent stability and unfolding of [Fe2-S2] ferredoxin of Halobacterium salinarum: spectroscopic investigations. Biophys. J. 79, 501-510. doi: 10.1016/S0006-3495(00)76312-0
Bhuyan, A. K. (2010). On the mechanism of SDS-induced protein denaturation. Biopolymers 93, 186-199. doi: 10.1002/bip.21318

Bonneté, F., Madern, D., and Zaccai, G. (1994). Stability against denaturation mechanisms in halophilic malate dehydrogenase "adapt" to solvent conditions. J. Mol. Biol. 244, 436-447. doi: 10.1006/jmbi.1994.1741

Coquelle, N., Talon, R., Juers, D. H., Girard, É., Kahn, R., and Madern, D. (2010). Gradual adaptive changes of a protein facing high salt concentrations. J. Mol. Biol. 404, 493-505. doi: 10.1016/j.jmb.2010.09.055

Costenaro, L., Zaccai, G., and Ebel, C. (2002). Link between protein-solvent and weak protein-protein interactions gives insight into halophilic adaptation. Biochemistry 41, 13245-13252. doi: 10.1021/bi025830z

Danson, M. J., and Hough, D. W. (1997). The structural basis of protein halophilicity. Comp. Biochem. Physiol. A Physiol. 117, 307-312. doi: 10.1016/S03009629(96)00268-X

Dodia, M. S., Bhimani, H. G., Rawal, C. M., Joshi, R. H., and Singh, S. P. (2008). Salt dependent resistance against chemical denaturation of alkaline protease from a newly isolated haloalkaliphilic Bacillus sp. Bioresour. Technol. 99, 6223-6227. doi: 10.1016/j.biortech.2007.12.020

Ebel, C., Costenaro, L., Pascu, M., Faou, P., Kernel, B., Proust-De Martin, F., et al. (2002). Solvent interactions of halophilic malate dehydrogenase. Biochemistry 41, 13234-13244. doi: 10.1021/bi0258290

Ebel, C., Faou, P., Kernel, B., and Zaccai, G. (1999). Relative role of anions and cations in the stabilization of halophilic malate dehydrogenase. Biochemistry 38, 9039-9047. doi: 10.1021/bi9900774

Eisenberg, H., Mevarech, M., and Zaccai, G. (1992). Biochemical, structural, and molecular genetic aspects of halophilism. Adv. Protein. Chem. 43, 1-62. doi: 10.1016/S0065-3233(08)60553-7

Esclapez, J., Camacho, M., Pire, C., and Bonete, M. J. (2013). "Biochemical analysis of halophilic dehydrogenases altered by site-directed mutagenesis," in Genetic Manipulation of DNA and Protein - Examples From Current Research, ed D. Figurski (InTech). doi: 10.5772/34565. Available online at: http://cdn.intechopen.com/pdfs/42535/InTech-Biochemical_analysis_of_halop hilic_dehydrogenases_altered_by_site_directed_mutagenesis.pdf

Esclapez, J., Pire, C., Bautista, V., Martínez-Espinosa, R. M., Ferrer, J., and Bonete, M. J. (2007). Analysis of acidic surface of Haloferax mediterranei glucose dehydrogenase by site-directed mutagenesis. FEBS Lett. 581, 837-842. doi: 10.1016/j.febslet.2007.01.054

Evilla, C., and Hou, Y. (2006). Acquisition of an insertion peptide for efficient aminoacylation by a halophile tRNA synthetase. Biochemistry 45, 6835-6845. doi: 10.1021/bi0521386

Ferrer, J., Cremades, R., Pire, C., and Bonete, M. J. (1998). Fluorescence and quenching comparative studies of halophilic and bovine glutamate dehydrogenase. J. Photochem. Photobiol. B. 47, 148-154. doi: 10.1016/S10111344(98)00214-0

Gafni, A., and Werber, M. M. (1979). Ferredoxin from Halobacterium of the Dead Sea. Structural properties revealed by fluorescence techniques. Arch. Biochem. Biophys. 196, 363-370. doi: 10.1016/0003-9861(79)90588-5

Gupta, A., and Khare, S. K. (2009). Enzymes from solvent tolerant microbes: useful biocatalysts for non-aqueous enzymology. Crit. Rev. Biotechnol. 29, 44-54. doi: 10.1080/07388550802688797

Hutcheon, G. W., Vasisht, N., and Bolhuis, A. (2005). Characterisation of a highly stable $\alpha$-amylase from the halophilic archaeon Haloarcula hispanica. Extremophiles 9, 487-495. doi: 10.1007/s00792-005-0471-2

Inouye, K., Kuzuya, K., and Tonomura, B. (1998). Sodium chloride enhances markedly the thermal stability of thermolysin as well as its catalytic activity. Biochim. Biophys. Acta 1388, 209-214. doi: 10.1016/S0167-4838(98) 00189-7

Irimia, A., Ebel, C., Madern, D., Richard, S. B., Cosenza, L. W., Zaccaï, G. et al. (2003). The oligomeric states of Haloarcula marismortui malate dehydrogenase are modulated by solvent components as shown by crystallographic and biochemical studies. J. Mol. Biol. 326, 859-873. doi: 10.1016/S0022-2836(02) 01450-X

Ishibashi, M., Arakawa, T., Philo, J. S., Sakashita, K., Yonezawa, Y., Tokunaga, H., et al. (2002). Secondary and quaternary structural transition of the halophilic archaeon nucleoside diphosphate kinase under high- and low-salt conditions. FEMS Microbiol. Lett. 216, 235-241. doi: 10.1111/j.1574-6968.2002.tb11441.x

Karan, R., and Khare, S. K. (2011). Stability of haloalkaliphilic Geomicrobium sp. protease modulated by salt. Biochemistry (Mosc.) 76, 686-693. doi: 10.1134/S0006297911060095 
Kumar, S., and Khare, S. K. (2012). Purification and characterization of maltooligosaccharide-forming alpha-amylase from moderately halophilic Marinobacter sp. EMB8. Bioresour. Technol. 116, 247-251. doi: 10.1016/j.biortech.2011.11.109

Lanyi, J. K. (1974). Salt-dependent properties of proteins from extremely halophilic bacteria. Bacteriol. Rev. 38, 272-290.

Larsen, R. W., Yang, J., Hou, S., Helms, M. K., Jameson, D. M., and Alam, M. (1999). Spectroscopic characterization of two soluble transducers from the archaeon Halobacterium salinarum. J. Protein Chem. 18, 269-275. doi: 10.1023/A:1021031227197

Li, X., Wang, H., Li, T., and Yu, H. (2012). Purification and characterization of an organic solvent-tolerant alkaline cellulase from a halophilic isolate of Thalassobacillus. Biotechnol. Lett. 34, 1531-1536. doi: 10.1007/s10529-0120938-z

Li, X., and Yu, H. Y. (2012). Purification and characterization of novel organic-solvent-tolerant $\beta$-amylase and serine protease from a newly isolated Salimicrobium halophilum strain LY20. FEMS Microbiol. Lett. 329, 204-211. doi: 10.1111/j.1574-6968.2012.02522.x

Lindgren, M., and Westlund, P. O. (2010). On the stability of chymotrypsin inhibitor 2 in a $10 \mathrm{M}$ urea solution. The role of interaction energies for ureainduced protein denaturation. Phys. Chem. Chem. Phys. 12, 9358-9366. doi: $10.1039 / \mathrm{b} 925726 \mathrm{~h}$

Madern, D., Camacho, M., Rodríguez-Arnedo, A., Bonete, M. J., and Zaccai, G. (2004). Salt-dependent studies of NADP-dependent isocitrate dehydrogenase from the halophilic archaeon Haloferax volcanii. Extremophiles 8, 377-384. doi: 10.1007/s00792-004-0398-z

Madern, D., and Ebel, C. (2007). Influence of an anion-binding site in the stabilization of halophilic malate dehydrogenase from Haloarcula marismortui. Biochimie 89, 981-987. doi: 10.1016/j.biochi.2007.03.008

Madern, D., Ebel, C., and Zaccai, G. (2000). Halophilic adaptation of enzymes. Extremophiles 4, 91-98. doi: 10.1007/s007920050142

Madern, D., Pfister, C., and Zaccai, G. (1995). Mutation at a single acidic amino acid enhances the halophilic behaviour of malate dehydrogenase from Haloarcula marismortui in physiological salts. Eur. J. Biochem. 230, 1088-1095. doi: 10.1111/j.1432-1033.1995.tb20659.x

Madern, D., and Zaccai, G. (1997). Stabilisation of halophilic malate dehydrogenase from Haloarcula marismortui by divalent cations. Eur. J. Biochem. 249, 607-611. doi: 10.1111/j.1432-1033.1997.00607.x

Madern, D., and Zaccai, G. (2004). Molecular adaptation: the malate dehydrogenase from the extreme halophilic bacterium Salinibacter ruber behaves like a non-halophilic protein. Biochimie 86, 295-303. doi: 10.1016/j.biochi.2004.04.004

Mevarech, M., Eisenberg, H., and Neumann, E. (1977). Malate dehydrogenase isolated from extremely halophilic bacteria of the Dead Sea. 1. Purification and molecular characteristics. Biochemistry 16, 3781-3785. doi: 10.1021/bi00636a009

Mevarech, M., Frolow, F., and Gloss, L. M. (2000). Halophilic enzymes: proteins with a grain of salt. Biophys. Chem. 86, 155-164. doi: 10.1016/S03014622(00)00126-5

Müller-Santos, M., de Souza, E. M., Pedrosa, F. O., Mitchell, D. A., Longhi, S., Carrière, F., et al. (2009). First evidence for the salt-dependent folding and activity of an esterase from the halophilic archaea Haloarcula marismortui. Biochim. Biophys. Acta 1791, 719-729. doi: 10.1016/j.bbalip.2009.03.006

Oren, A. (2008). Microbial life at high salt concentrations: phylogenetic and metabolic diversity. Saline Syst. 4, 2. doi: 10.1186/1746-1448-4-2

Oren, A. (2013). Life at high salt concentrations, intracellular $\mathrm{KCl}$ concentrations, and acidic proteomes. Front. Microbiol. 4:315. doi: 10.3389/fmicb.2013.00315

Polosina, Y. Y., Zamyatkin, D. F., Kostyukova, A. S., Filimonov, V. V., and Fedorov, O. V. (2002). Stability of Natrialba magadii NDP kinase? comparisons with other halophilic proteins. Extremophiles 6, 135-142. doi: $10.1007 / \mathrm{s} 007920100232$

Pundak, S., and Eisenberg, H. (1981). Structure and activity of malate dehydrogenase of the extreme halophilic bacteria of the Dead Sea. 1. Conformation and interaction with water and salt between $5 \mathrm{M}$ and $1 \mathrm{M} \mathrm{NaCl}$ concentration. Eur. J. Biochem. 118, 463-470. doi: 10.1111/j.1432-1033.1981.tb05542.x

Rao, L., Zhao, X., Pan, F., Li, Y., Xue, Y., Ma, Y., et al. (2009). Solution behavior and activity of a halophilic esterase under high salt concentration. PLOS ONE 4:e6980. doi: 10.1371/journal.pone.0006980
Richard, S. B., Madern, D., Garcin, E., and Zaccai, G. (2000). Halophilic adaptation: novel solvent protein interactions observed in the 2.9 and $2.6 \AA$ resolution structures of the wild type and a mutant of malate dehydrogenase from Haloarcula marismortui. Biochemistry 39, 992-1000. doi: 10.1021/ bi991001a

Shafiei, M., Ziaee, A. A., and Amoozegar, M. A. (2011). Purification and characterization of an organic-solvent-tolerant halophilic $\alpha$-amylase from the moderately halophilic Nesterenkonia sp. strain F. J. Ind. Microbiol. Biotechnol. 38, 275-281. doi: 10.1007/s10295-010-0770-1

Sinha, R., and Khare, S. K. (2013a). Characterization of detergent compatible protease of a halophilic Bacillus sp. EMB9?: differential role of metal ions in stability and activity. Bioresour. Technol. 145, 357-361. doi: 10.1016/j.biortech.2012.11.024

Sinha, R., and Khare, S. K. (2013b). “Thermostable proteases," in Thermophilic Microbes in Environmental and Industrial Biotechnology, eds T. Satyanarayana, J. Littlechild, and Y. Kawarabayasi (Dordrecht: Springer), 859-880. doi: 10.1007/978-94-007-5899-5_32

Souza, T. A., Okamoto, D. N., Ruiz, D. M., Oliveira, L. C., Kondo, M. Y., Tersario, I. L., et al. (2012). Correlation between catalysis and tertiary structure arrangement in an archaeal halophilic subtilase. Biochimie 94, 798-805. doi: 10.1016/j.biochi.2011.11.011

Tadeo, X., López-Méndez, B., Trigueros, T., Laín, A., Castaño, D., and Millet, O. (2009). Structural basis for the aminoacid composition of proteins from halophilic archea. PLoS Biol. 7:e1000257. doi: 10.1371/journal.pbio. 1000257

Takita, T., Aono, T., Sakurama, H., Itoh, T., Wada, T., Minoda, M., et al. (2008). Effects of introducing negative charges into the molecular surface of thermolysin by site-directed mutagenesis on its activity and stability. Biochim. Biophys. Acta 1784, 481-488. doi: 10.1016/j.bbapap.2007.12.004

Talon, R., Coquelle, N., Madern, D., and Girard, E. (2014). An eperimental point of view on hydration/ solvation in halophilic proteins. Front. Microbiol. 5:66. doi: 10.3389/fmicb.2014.00066

Tannous, E., Yokoyama, K., You, D. J., Koga, Y., and Kanaya, S. (2012). A dual role of divalent metal ions in catalysis and folding of RNase $\mathrm{H} 1$ from extreme halophilic archaeon Halobacterium sp. NRC-1. FEBS Open Bio. 2, 345-352. doi: 10.1016/j.fob.2012.10.003

Tokunaga, H., Arakwa, T., and Tokunaga, M. (2008). Engineering of halophilic enzymes: two acidic amino acid residues at the carboxy-terminal region confer halophilic characteristics to Halomonas and Pseudomonas nucleoside diphosphate kinases. Protein Sci. 17, 1603-1610. doi: 10.1110/ps.035 725.108

Tokunaga, H., Ishibashi, M., Arakawa, T., and Tokunaga, M. (2004). Highly efficient renaturation of $\beta$-lactamase isolated from moderately halophilic bacteria. FEBS Lett. 558, 7-12. doi: 10.1016/S0014-5793(03)01508-4

Wright, D. B., Banks, D. D., Lohman, J. R., Hilsenbeck, J. L., and Gloss, L. M. (2002). The effect of salts on the activity and stability of Escherichia coli and Haloferax volcanii dihydrofolate reductases. J. Mol. Biol. 323, 327-344. doi: 10.1016/S00222836(02)00916-6

Zaccai, G. (2013). Hydration shells with a pinch of salt. Biopolymers 99, 233-238. doi: 10.1002/bip.22154

Conflict of Interest Statement: The authors declare that the research was conducted in the absence of any commercial or financial relationships that could be construed as a potential conflict of interest.

Received: 30 December 2013; accepted: 27 March 2014; published online: 09 April 2014.

Citation: Sinha $R$ and Khare SK (2014) Protective role of salt in catalysis and maintaining structure of halophilic proteins against denaturation. Front. Microbiol. 5:165. doi: 10.3389/fmicb.2014.00165

This article was submitted to Extreme Microbiology, a section of the journal Frontiers in Microbiology.

Copyright (c) 2014 Sinha and Khare. This is an open-access article distributed under the terms of the Creative Commons Attribution License (CC BY). The use, distribution or reproduction in other forums is permitted, provided the original author(s) or licensor are credited and that the original publication in this journal is cited, in accordance with accepted academic practice. No use, distribution or reproduction is permitted which does not comply with these terms. 